Zofia Berdychowska ๑

Uniwersytet Jagielloński, Kraków

zofia.berdychowska@uj.edu.pl

\title{
KOMUNIKACJA W PRZESTRZENI MIEJSKIEJ ZMIENIAJĄCA STANDARDY ZACHOWANIA W DOBIE PANDEMII SARS-COV-2 ${ }^{1}$
}

Słowa klucze: praktyki komunikacyjne, krajobraz językowy miasta, krótkie teksty, zwięzłość językowa tekstu, zmiany językowe

Keywords: communication practices, urban linguistic landscape, brief texts, linguistic brevity, linguistic changes

\section{Wprowadzenie}

Rozporządzenia dotyczące sposobów zachowania i stosowania środków ochrony osobistej służących tłumieniu pandemii wywołanej przez wirus SARS-CoV-2 głęboko ingerują w życie codzienne, tworząc od chwili zdiagnozowania w Polsce 4 marca 2020 r. „pacjenta zero” nową rzeczywistość - koronarzeczywistość ${ }^{2}$. Konieczność wdrożenia nowych norm zachowania służących ochronie przed zakażeniem wirusem spowodowała pojawienie się w przestrzeni publicznej krótkich komunikatów, których celem jest zmiana zachowań społecznych. „Otekstowujące” przestrzeń publiczną komunikaty (Betextung des öffentlichen Raumes, Domke 2014) kształtują

1 Anonimowym Recenzentom dziękuję za poświęcony lekturze czas i cenne krytyczne uwagi.

2 Por. tytuł artykułu Agnieszki Cierpich-Kozieł (2020) o nowych złożeniach z członem koronai wzmiankowaną tam dyskusję na temat form korono- i korona-. Określenie koronarzeczywistość pojawia się już 3 kwietnia 2020 r., w niespełna miesiąc od zidentyfikowania "pacjenta zero": „[...] korzystamy jednak z przywileju nieuczestniczenia w koronarzeczywistości” (https://inver so.pl/blog/zostanwdomu-lukasz-najder, dostęp: 9 III 2021). 
jej krajobraz językowy (Landry, Bourhis 1997: 23)³ i konstytuują ją pod względem fizycznym, społecznym i komunikacyjnym w nowy sposób.

Celem artykułu jest próba uchwycenia określonych potrzebami społecznymi praktyk komunikacyjnych stosowanych $\mathrm{w}$ miejskiej przestrzeni publicznej doby pandemii i cechujących je zjawisk językowych. Materiał zgromadzony między listopadem $2020 \mathrm{r}$. i marcem $2021 \mathrm{r}$. obejmuje blisko 250 sfotografowanych komunikatów napotkanych między jednym $\mathrm{z}$ osiedli mieszkaniowych $\mathrm{w}$ północno-zachodniej części Krakowa i śródmieściem. W aspekcie poznawczym można wyróżnić grupy komunikatów odnoszące się do rekomendowanych - względnie obowiązujących - głównych zasad zachowania w przestrzeni publicznej oraz ich następujących aspektów: zabiegów higieniczno-sanitarnych (mycie i dezynfekcja rąk, używanie rękawiczek ochronnych), zachowania dystansu społecznego (dystans między osobami, ograniczenie liczby osób przebywających w pomieszczeniu, konsumpcja przy oddalonych od siebie stolikach i poza lokalem) oraz zasłaniania ust i nosa (w pomieszczeniach i na zewnątrz, w wypadku konsumpcji poza lokalem).

\section{Forma tekstowa praktyk komunikacyjnych}

Ponieważ narzędziem praktyk komunikacyjnych są teksty, najpierw podjęta zostanie próba określenia analizowanych komunikatów jako form tekstowych pod względem charakterystycznej długości i postaci semiotycznej.

\subsection{Teksty krótkie i drobne}

Długość tekstu bywa wyznaczana a priori liczbą znaków lub wyrazów. Dotyczy to nie tylko artykułów składanych do czasopism naukowych, abstraktów referatów konferencyjnych, lecz również określonych, nowych gatunków multimedialnych, jak tłit (tweet), i pewnych gatunków tekstów literackich, jak flash-fiction, sudden fiction, twiction, w przeciwieństwie do krótkich, lecz nielimitowanych liczbą znaków opowiadań, które pojawiały się już w wieku XIX ${ }^{4}$. W odróżnieniu od krótkich form literackich krótkość takich tekstów jak slogany reklamowe, hasła pojawiające się na demonstracjach, nagłówki prasowe czy paski informacyjne (live-ticker) nie stanowi cechy gatunkowej. Jak podkreśla Vincent Balnat (2013: 91-92), omawiając krótkość

3 Pojęcie linguistic landscape stało się punktem wyjścia dla ramy teoretycznej analiz między innymi wielojęzycznej, a następnie multimedialnej komunikacji w przestrzeni publicznej. Ulrich Schmitz już w tytule programowego dla tej ostatniej artykułu (2018) wysuwa postulat uprawiania lingwistyki jako lingwistyki mediów. https://oe1.orf.at/artikel/381476/Kurz-und-Kuerzesttexte (dostęp: 30 IX 2018). 
w poszczególnych podsystemach języka, istotny jest aspekt nie ilościowy, lecz jakościowy. Krótkie formy tekstowe wyróżnia duża kondensacja treści, a co za tym idzie gęstość semantyczno-syntaktyczna. Część z nich, o ograniczonej autonomii, jak abstrakty, streszczenia czy przedmowy, to metatekstowe komprymacje dłuższych tekstów. Inną, znacznie bardziej heterogeniczną grupę stanowią krótkie teksty o także funkcjonalnie mocno ograniczonej objętości znakowej, ale autonomiczne.

Takie krótkie „drobne teksty” (kleine Texte, Hausendorf 2009) to między innymi reklamy, plakaty, zapowiedzi na cyfrowych tablicach informacyjnych, na dworcach i lotniskach. Należą do nich także omawiane tutaj krótkie komunikaty ${ }^{5}$. Są one wprawdzie zakorzenione $\mathrm{w}$ aktach prawnych dotyczących zapobiegania transmisji wirusa i ten rodzaj intertekstualności bywa w nich ujawniany (Zgodnie z wytycznymi GIS; W zwiq̨zu z rozporządzeniem Prezesa Rady Ministrów; Zgodnie z rozporzadzeniem Rady Ministrów), ale nie stanowią ich skróconych form.

Heiko Hausendorf (ibid.) uważa drobne teksty za marginalne zjawisko tekstowości, ale ich rola w komunikacji społecznej wciąż rośnie. Możliwość postrzegania i przetwarzania komunikatów przez odbiorcę w przestrzeni publicznej jest wyznaczana przez szczupłe granice powierzchni i czasu, jakie ma do dyspozycji nadawca. Stąd krótkie (drobne) komunikaty zanurzone w kontekście cechuje językowa zwięzłość i jednocześnie dobitność, osiągane różnymi środkami językowymi i pozajęzykowymi, między innymi przez stosowanie impresywnych środków wyrazu, niepełną realizację potencjału konotacyjnego predykatu, użycie wypowiedzeń niezdaniowych, a także dzięki interakcji z obrazem i kontekstem, w którym są zanurzone.

\subsection{Postać semiotyczna}

Według Ulricha Schmitza tekst czysto językowy stanowi zewnętrznie ograniczoną (na przykład przez niewypełnione interwały czasowe lub powierzchnie) strukturę znakową, która zawiera co najmniej jeden znak językowy (Schmitz 2016: 331, 333). Rodzaj niewypełnienia implikuje postać semiotyczną tak oznaczonej struktury: niewypełnione interwały czasowe - audialną, niewypełnione powierzchnie - wizualną. Tę ostatnią monomodalny tekst werbalny dzieli z obrazem. Mimo to, jak

5 Hausendorf (2009) odnosi cechę klein 'mały, drobny' również do innych aspektów. W niemieckich badaniach brak jest zgodności co do terminologii. Obok kleine Texte występuje złożenie Kleintexte, obok kurze Texte złożenie Kurztexte 'krótkie teksty', jak również Zero- i Minitexte (por. Liedtke, Berdychowska 2020: 8 i wskazana tam literatura). Wyodrębnienie przez Ninę Janich (2015) Kurztexte jako jednego z podtypów kurze Texte dało początek badaniom nad ich dalszą dyferencjacją. W celu odgraniczenia od szerszego pojęcia krótkich tekstów proponuję dla krótkich, autonomicznych tekstów użytkowych, charakteryzujących się językową zwięzłością, określenie „drobne teksty, drobne komunikaty”, specyfikujące nie gatunek, lecz typ, względnie wprowadzony do genologii przez Marię Wojtak gatunek w formie kolekcji (Wojtak 2006). 
konstatuje Konrad Ehlich, obrazy nie są tekstami, ponieważ każda z tych modalności znakowych wykorzystuje sobie tylko właściwy potencjał semantyczny (Ehlich 2007: 615), przetwarzany w procesach tworzenia i rozumienia komunikatu w sposób specyficzny dla danej modalności. Natomiast jako jedna z modalności znakowych obrazy konstytuują lub wraz z innymi modalnościami znakowymi współkonstytuują znaczenie przekazu. Przekaz taki to w ujęciu Schmitza (2018) tekst multimodalny, jeżeli stanowi zewnętrznie ograniczoną strukturę znakową, która zawiera co najmniej jeden znak językowy i która wykorzystuje co najmniej dwie z pięciu możliwości semiotycznego przekazywania znaczeń, tj. język mówiony, język pisany, obraz statyczny, obraz ruchomy i dźwięk.

Treść interesujących nas tutaj komunikatów bywa wyrażana nie tylko przy użyciu znaków językowych. Niezależnie od tego, czy realizowane są tylko werbalnie czy też towarzyszą im na przykład piktogramy, w konstytuowaniu ich znaczenia jako elementu krajobrazu miasta uczestniczy również otoczenie i miejsce, w którym są umieszczone, a także ich materialność. Zaliczają się one zatem do tekstów multimodalnych.

\section{Praktyki komunikacyjne}

Praktyki komunikacyjne, tj. zbiory podejmowanych działań komunikacyjnych, w którym zakotwiczone są konkretne indywidualne działania komunikacyjne (Kulczycki 2015: 57-58), determinowane są przez potrzeby społeczne. Strategiczną funkcją praktyk komunikacyjnych stosowanych $\mathrm{w}$ przestrzeni publicznej doby pandemii wywołanej wirusem SARS-CoV-2 jest regulowanie zachowań społecznych przez odwołanie do różnych rozwiązań organizacyjnych. Narzędzia tych praktyk, tj. krótkie (drobne) teksty o funkcji głównie apelatywnej (prośby, apele, nakazy i zakazy) i informacyjnej (objaśnienia), a częściowo także fatycznej, odbiorca interpretuje w ramach sytuacji działania i kontekstu pandemii.

\subsection{Lokalizacja i materialność komunikatów}

Komunikaty, umieszczane $\mathrm{z}$ reguły za przeszklonymi drzwiami wejściowymi lub blisko wejścia w oknach wystawowych czy witrynach sklepowych oraz przy wejściach do budynków użyteczności publicznej, takich jak urzędy pocztowe, sklepy, restauracje, kawiarnie ${ }^{6}$, odróżniają się od takich standardowych zawiadomień jak

6 W materiale badawczym przykłady umieszczenia komunikatu regulującego zachowanie przy wejściu do budynku mieszkalnego to absolutne wyjątki. Natomiast spotyka się je wewnątrz budynku, jako na przykład komunikaty o częstym dezynfekowaniu klamek i uchwytów przez 
Otwarte/Zamknięte w kilku aspektach. Białe lub zwracające uwagę intensywnie żółte kartki papieru formatu A4 stanowią standardową powierzchnię materialną wywieszek doby pandemii. Dominują wydruki komputerowe, czarna czcionka wielkości czytelnej z odległości około dwóch metrów (i większej) oraz komunikaty sporządzone ad hoc odręcznie. W komunikatach sklepów należących do jednej sieci, co sygnalizuje umieszczone na nich logo, widoczna jest unifikacja treści i formy. Komunikaty związane z okresowo obowiązującymi obostrzeniami odnoszącymi się do spożywania posiłków w lokalu pojawiają się także wraz z ofertą dnia na tablicach wystawianych przed wejściem do niektórych lokali gastronomicznych, najczęściej zapisane kredą. Najmniej liczna grupa, wykorzystująca dwukrotnie większy format białego papieru oraz wyróżnienia treści za pomocą koloru i wielkości czcionki, to oficjalne plakaty i plakatowe druki instytucjonalne, autoryzowane (Kancelaria Prezesa Rady Ministrów, NFZ, Poczta Polska) i opatrzone logo, dostępne w internecie. W wielkopowierzchniowych sklepach komunikaty przypominające o obowiązku noszenia masek, zachowania dystansu i dezynfekcji rąk przyjmują również formę audialną7. Opisana nietrwała materialność, kontrastująca $\mathrm{z}$ trwalszym materiałem standardowych wywieszek, pismo odręczne, sposób mocowania komunikatów (od wewnątrz na szybach taśmą klejącą lub klejem), a także wskazania czasu obowiązywania określonych regulacji świadczą o ogólnym nastawieniu na ich tymczasowość. Jednocześnie uderza mnogość i różnorodność stosowanych uwydatnień treści. Poza pogrubieniami (także w piśmie ręcznym) nadawcy uwydatniają ich zdaniem najważniejsze treści przez zróżnicowanie typu, wielkości i koloru czcionki oraz podkreślenie i wykrzyknik, które bywają zwielokrotniane. Do zabiegów uwydatniających treść można w odniesieniu do omawianych komunikatów zaliczyć interakcję słowa z obrazem, która polega na przedstawianiu tych samych zaleceń przez dwa różne systemy znakowe:

(1) W naszym sklepie obowiązuje [piktogram: głowa w masce medycznej] zakrywanie ust i nosa [piktogram: dwie osoby oddalone od siebie, jedna $\mathrm{z}$ wyciągniętą ręką sygnalizującą żądanie zachowania dystansu] dystans 1,5 metra [piktogram pojemnika z pompką i znakiem krzyżyka aptecznego] dezynfekcja rąk $\mathrm{k}^{8}$.

obsługę budynku lub prośby o niepozostawianie w związku z pandemią (sic!) worków ze śmieciami nawet na chwilę na klatce schodowej.

7 Przykładem są komunikaty nadawane w regularnych odstępach czasu w sklepach sieci Auchan.

8 Brzmienie komunikatów przytaczane jest ze względu na oszczędność miejsca bez zachowania układu treści, ale z zachowaniem oryginalnej pisowni, znaków przestankowych oraz ich braku, a także wyróżnień przez wytłuszczenia lub podkreślenia. W nawiasach kwadratowych poprzedzających odpowiedni fragment tekstu umieszczono informacje dotyczące towarzyszących elementów graficznych oraz symbolicznie notowanego zróżnicowania czcionki: $\uparrow$ zwiększenie czcionki; $\downarrow$ zmniejszenie czcionki; [+] początek zmiany / [-] koniec zmiany koloru czcionki; [cz] czcionka czerwona; [b] czcionka biała; [r] pismo odręczne. 
Jak pokazują przytaczane dalej przykłady, zdarza się stosowanie różnych sposobów wyróżnienia treści w tym samym komunikacie, przy czym w podobnie brzmiących komunikatach bywają to inne elementy treści: Informujemy, że osoby niezasłaniające nosa oraz ust nie będa obstugiwane vs. [wersaliki] Przypominamy o obowiązku zakładania [+cz] maseczek [-cz] w sklepie !! Klienci bez maseczek nie będą obsługiwani. Nagromadzenie i duże zróżnicowanie form uwydatniania treści w jednym tekście zdaje się jednak nie służyć dobrze lepszemu zrozumieniu przesłania.

\subsection{Instancja nadawcza i odbiorcza}

Komunikaty umieszczane przy wejściach lub na drzwiach prowadzących do lokali użytkowych i budynków użytku publicznego cechuje ogólna dostępność. Adresowane są do każdego, kto zamierza wejść. Formy adresatywne standardowo realizują funkcję fatyczną języka. Kontekst pandemii pozwala uznać za realizację funkcji fatycznej zarówno wyartykułowaną troskę o bezpieczeństwo obu stron, tj. klientów i personelu, poprzedzoną lub niepoprzedzoną formami adresatywnymi ((2), (3)), podziękowania (7a) i kończące komunikat przeprosiny (Dziękujemy; Dziękujemy za zrozumienie; Przepraszamy), jak i takie wypowiedzenia niezdaniowe, jak Uwaga, Stop. Te ostatnie służą zwróceniu uwagi na treść komunikatu ((4), (5)), podczas gdy w prototypowych kontekstach jako elementy innego dyspozytywu (na przykład znaku drogowego, por. Liedtke 2020) wyrażają ostrzeżenie lub są leksykalnymi wykładnikami nakazu zatrzymania się:

(2) Szanowni Klienci. Uprzejmie informujemy, że wobec zagrożenia epidemicznego, w trosce o bezpieczeństwo Państwa oraz naszych Pracowników preferujemy płatności kartami płatniczymi. [Poniżej piktogram dłoni trzymającej kartę płatniczą]

(3) NA TERENIE SKLEPU MOŻE PRZEBYWAĆ MAKSYMALNIE 10 KLIENTÓW. STOSOWANIE SIĘ DO POWYŻSZYCH ZASAD JEST ISTOTNE DLA BEZPIECZEŃSTWA PAŃSTWA ORAZ PERSONELU. ZARZĄD FIRMY NN [+ logo]

(4) STOP!!! Obowiązkowo załóż maseczkę lub zakryj twarz chustą przed wejściem do sklepu

(5) UWAGA !!! ZAPOTRZEBOWANIA NA LEKI PRZYMUJEMY TYLKO TELEFONICZNIE (PROSZE NIE PRZYNOSIĆ KARTEK O LEKI)

Dystansowe i uprzejme formy adresatywne: Szanowni / Drodzy Klienci / Państwo / Kochani Seniorzy, występują zwykle na początku, ale jako wykrzyknienie oddzielające treści i ponownie zwracające uwagę odbiorcy również wewnątrz tekstu. Zdarzają się niekonsekwencje $w$ stosowaniu form adresatywnych $w$ ramach jednego 
komunikatu (6) lub w występujących obok siebie komunikatach tworzących serię $((7 a)-(7 c))$ oraz przejścia od formy bezosobowej do poufałej formy adresatywnej (8):

(6) JEŻELI W OKRESIE OSTATNICH 14 DNI PRZEBYWAŁ(A) PAN(I) W REJONACH TRANSMISJI KORONAWIRUSA [ ] (LISTA KRAJÓW PUBLIKOWANA CODZIENNIE NA STRONIE WWW.GIS.GOV.PL) [ $\uparrow]$ LUB MIAŁ(A) PAN(I) KONTAKT Z OSOBĄ U KTÓREJ POTWIERDZONO ZAKAŻENIE KORONAWIRUSEM NIE WCHODŹ DO PRZYCHODNI !!! SKONTAKTUJ SIE Z NAMI TELEFONICZNIE LUB Z NAJBLIŻSZA STACJĄ SANEPIDU !!!

(7a) SZANOWNI KLIENCI! W trosce o Klientów oraz Pracowników Poczty Polskiej prosimy o zachowanie odległości około $\mathbf{1 , 5} \mathbf{m}$ podczas oczekiwania na obsługę przy okienku i pozostanie za znajdującą się na podłodze taśmą także w trakcie obsługi. Pracownicy Poczty będą kolejno prosić Państwa o podchodzenie do stanowiska obsługi. Bliżej do Pracownika prosimy podchodzić jedynie w celu okazania dokumentów i innych niezbędnych czynności, na wyraźną prośbę Pracownika. DZIĘKUJEMY! [+logo Poczty Polskiej]

(7b) [+b, czerwone tło] COVID-19 [-b] [+cz, białe tło w czerwonym obramowaniu] ZACHOWAJ WŁAŚCIWĄ ODLEGŁOŚĆ 2 metry [+logo Poczty Polskiej]

(7c) Informujemy [w następnym wierszu:] w tej Placówce Pocztowej może równocześnie przebywać maksymalnie 2 osób (z wyłączeniem obsługi) [+logo Poczty Polskiej]

(8) Prosimy $[\downarrow \downarrow \downarrow]$ wchodzić $[\uparrow \uparrow \uparrow \uparrow]$ POJEDYNCZO $[\downarrow \downarrow]$ - pamiętaj o masce

Z tekstów tych niewiele można się dowiedzieć o nadawcy. Albo nie jest on eksplikowany (4), albo identyfikuje się jako nadawca zbiorowy przez użycie zaimka 1 os. 1. mn., co można odnieść zarówno do instytucji, właściciela, jak i osób zatrudnionych w konkretnej placówce (2), sporadycznie identyfikatorem bywa nazwa firmy $\mathrm{i} / \operatorname{lub}$ logo, jak w przykładach (7a)-(7c).

\subsection{Wskaźniki illokucji}

Dyrektywność (prośba, zalecenie, ostrzeżenie, zakaz, nakaz) jako dominująca illokucja bywa wyrażana wprost przez użycie trybu rozkazującego (załóż maseczkę ochronna / włóż maskę ochronna poczekaj na zaproszenie do środka / zasłoń usta i nos) w zdaniu głównym wprowadzonym przez czasowniki prosić, przypominać, zalecać (Proszę wchodzić pojedynczo / Przypominamy o konieczności zasłaniania nosa i ust w pomieszczeniach zamkniętych / Zaleca się płacenie karta płatnicza). Jest także realizowana $\mathrm{w}$ zdaniu podrzędnym wprowadzonym przez czasownik informować. Główny ciężar wyrażania dyrektywności spoczywa na predykatach 
modalnych wyrażających powinność lub konieczność oraz na formach fundowanych na bazie obowiąz-, której struktura semantyczna zawiera jako główny element obligację stosowania się do nakazów. Tylko w jednym komunikacie ((11) - zob. druga część komunikatu) chodzi o zniesienie nakazu:

(9) W sklepie powinna znajdować się jedna osoba

(10) Trzeba zasłaniać nos i usta najlepiej maseczką

(11) W naszym sklepie obowiązuje zakrywanie ust i nosa / Od 1.02. godziny dla seniorów nie obowiązują.

(12) [...] jest obowiązek zakrywania ust i nosa; [...] prosimy stosować się do powyższego rozporządzenia

(13) Przed wejściem do sklepu OBOWIĄZKOWO zasłoń usta i nos maseczką lub chustą!

(14) W naszych placówkach zakrywanie ust i nosa jest obowiązkowe

SJP PWN 2004, podobnie jak aktualna wersja internetowa SJP PWN tak objaśniają czasownik obowiązywać: 'być czyimś obowiązkiem; być powszechnie uznaną zasadą, zwyczajem, prawem; mieć moc prawną', WSJP PAN definiuje obowiązywać jako 'być powszechnie lub prawnie uznawanym za taki, którego należy przestrzegać'. Rzeczownik obowiązek w tym znaczeniu to według SJP PWN 2004 'konieczność zrobienia czegoś wynikająca $\mathrm{z}$ nakazu wewnętrznego (moralnego), administracyjnego, prawnego; to, co ktoś musi zrobić powodowany tą koniecznością; powinność, zobowiązanie', w nowszej wersji internetowej: 'konieczność zrobienia czegoś wynikająca $\mathrm{z}$ nakazu moralnego lub prawnego; też: to, co ktoś musi zrobić powodowany taką koniecznością' (SJP PWN), odpowiednio zaś WSJP PAN 'coś, co jakaś osoba musi zrobić, bo nakazują to normy społeczne lub prawne'. Natomiast obowiązkowo znaczy 'zgodnie z ustalonym obowiązkiem, zgodnie z poczuciem obowiązku; przymusowo' (SJP PWN 2004), 'zgodnie z ustalonymi obowiązkami' (WSJP PAN).

$\mathrm{W}$ jednym $\mathrm{z}$ komunikatów nadawca zmienia perspektywę i zamiast nakładania na adresata obowiązku przenosi na niego odpowiedzialność, czyli 'konieczność, obowiązek moralny lub prawny odpowiadania za swoje czyny i ponoszenia za nie konsekwencji; odpowiadanie przed kimś, wobec kogoś, za kogoś lub za coś' (SJP PWN 2004), 'obowiązek moralny lub prawny odpowiadania za swoje lub czyjeś czyny' (SJP PWN), 'obowiązek dopilnowania kogoś lub czegoś' (WSJP PAN):

(15) Odpowiedzialność za brak maseczki na terenie sklepu ponosi klient. 


\section{Praktyki językowe}

Poza powyższymi praktykami związanymi $\mathrm{z}$ wyrażaniem kluczowych $\mathrm{w}$ komunikatach doby pandemii illokucji dyrektywnych zwrócę tutaj uwagę jedynie na wybrane, moim zdaniem najistotniejsze zjawiska w użyciu języka w komunikatach-wywieszkach.

\subsection{Zmiany semantyczne}

Do istotnych zjawisk w praktykach językowych zaliczam niedostrzegane, ale wpływające na perswazyjną skuteczność komunikacji zmiany w strukturze semantycznej leksemów maska, maseczka oraz spostrzeżone innowacje językowe.

\subsubsection{Maska, maseczka}

Maska, dowartościowana jako „nasze jedyne powszechne narzędzie do walki z pandemią" ${ }^{\prime}$ występuje w drobnych komunikatach szczególnie często, także w formie deminutywnej maseczka, kojarzonej w pierwszym rzędzie z nakładaniem bezpośrednio na twarz grubej warstwy kosmetyku. W tym użyciu odbiega przeznaczeniem i sytuacją stosowania od swojego podstawowego znaczenia 'zasłona na twarz (albo część twarzy) z otworami na oczy, nakładana podczas maskarady, obrzędów ludowych lub przez aktorów w teatrze; też: osoba z tak zasłoniętą twarzą' (SJP PWN 2004). WSJP PAN (dostęp: 9 II 2021) podaje jako drugie z siedmiu znaczeń 'osłona zakładana na twarz w celu uniknięcia kontaktu ze szkodliwymi czynnikami' i przyporządkowuje pojęcie tematycznie do innej grupy, mianowicie do grupy CODZIENNE ŻYCIE CZŁOWIEKA $\rightarrow$ praca $\rightarrow$ materiały i narzędzia pracy. Odnotowane możliwe połączenia specyfikujące to maska gazowa, przeciwgazowa, przeciwpyłowa; chirurgiczna, szermiercza. Także aktualna wersja hasła maska (i zdrobnienia maseczka) w internetowym SJP PWN uwzględnia jako piąte znaczenie 'osłona twarzy chroniąca ją przed działaniem szkodliwych substancji lub przed urazami; też: osłona na nos i usta zapobiegająca rozsiewaniu zarazków' (dostęp: 23 III 2021). Maska chirurgiczna (niesłusznie utożsamiana z maską medyczną) nie jest ani przebraniem, ani kostiumem, ani odciskiem twarzy, lecz osłoną. W analizowanych komunikatach występuje obok innych (na przykład chusta) lub niespecyficznych (na przykład inne zabezpieczenia), względnie niewyspecyfikowanych przez niewypełnienie miejsca argumentowego narzędzi osłonowych z czasownikami zakrywać, zasłonić; założyć /

9 https://www.edziecko.pl/rodzice/7,79361,26807083,konferencja-ministra-zdrowia-nowe-obo strzenia-luty-2021-chodzi.html\#e=RelRecImg4 (dostęp: 19 II 2021). 
zakładać, osłonić, z których dwa początkowe połączenia odpowiadają funkcji maski w znaczeniu przebrania, następne funkcji maski (przeciw)gazowej / przeciwpyłowej, ale tylko ostatnie odpowiada funkcji maski chirurgicznej / medycznej jako bariery ${ }^{10}$ stosowanej w celu ograniczenia rozprzestrzeniania się infekcji.

(16) Obowiązkowo załóż maseczkę lub zakryj twarz chustą przed wejściem do sklepu

(17) Prosimy wchodzić w maseczkach lub innych zabezpieczeniach twarzy

(18) Zasłaniaj nos i usta najlepiej maseczką

Widoczne jest niekonsekwentne stosowanie predykatów nazywających czynność, bez rozróżnienia funkcji zasłony i osłony, a także rozszerzanie powierzchni do osłonięcia - z ust i nosa (także w kolejności „nosa i ust”) na całą twarz. W żadnym z komunikatów nie ujawnia się nadal słabo zakotwiczona w świadomości funkcja (określonego typu) maski polegająca na ochronie nie tylko osoby ją noszącej, lecz również otoczenia, jako nowy, poszerzający treść i zawężający zakres element struktury semantycznej leksemu.

\subsubsection{Dostawy i wynosy}

W komunikatach dwóch różnych lokali gastronomicznych pojawiła się innowacyjna forma wynosy (fot. 1 i 2), w dwóch komunikatach towarzyszy jej forma dostawy:

(19) [na kredowej tablicy ustawionej przed lokalem], [r] Pierożki DIM SUM GRATIS DO KAŻDEGO WYNOSU

(20) DOSTAWY \& WYNOSY

Powstanie tych form wiąże się z operacją semantyczno-syntaktyczną. W SJP PWN 2004 rzeczownik dostawa objaśniono następująco:

1. «dostarczanie towarów, zaopatrzenie» Dostawa żywności, mleka. Zorganizować dostawę węgla.

2. «to, co się dostarcza» Zmniejszenie dostaw wody dla miasta.

10 [maska medyczna] „Stanowi środek zmniejszający ryzyko zakażenia drogą kropelkową. Ogranicza możliwość dostania się zanieczyszczeń, bakterii i wirusów do jamy ustnej i nosa oraz znacząco zmniejsza wydostanie się ich na zewnątrz" [wyróżnienie - Z.B.] (https://www.allecco. pl/maska-medyczna-jednorazowa-50-szt.html (dostęp: 15 III 2021)). 


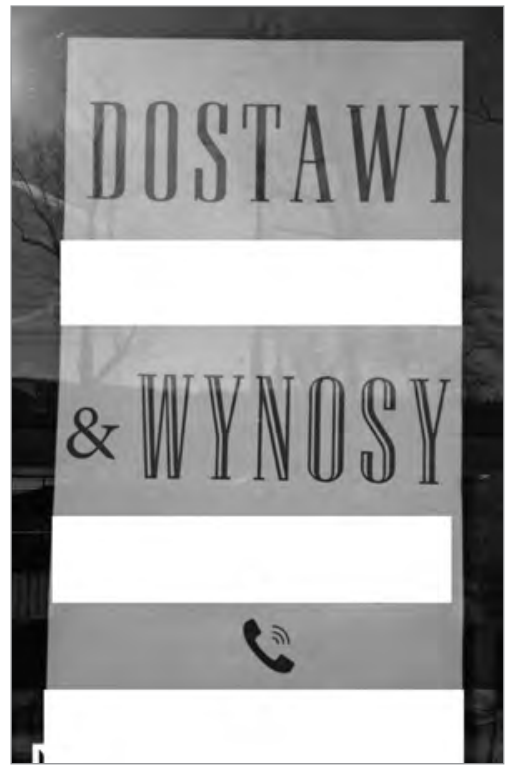

Fot. 1

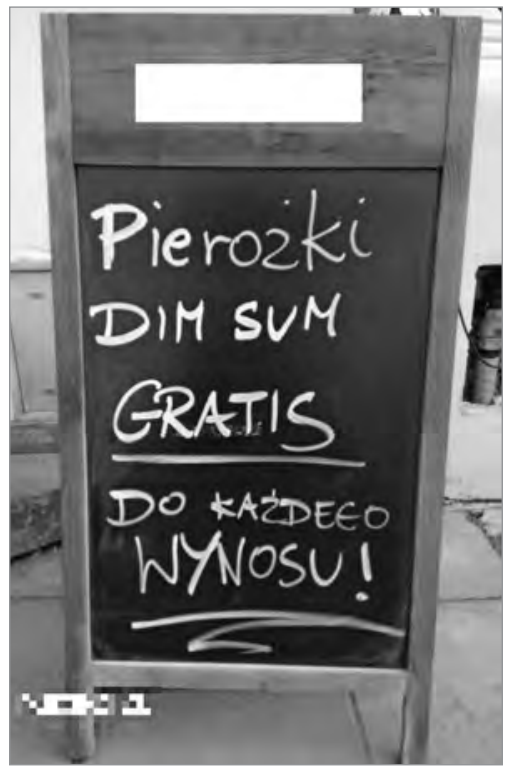

Fot. 2

WSJP PAN także podaje dwa warianty znaczeniowe hasła dostawa:

1.a 'dostarczenie lub dostarczanie czegoś w określone miejsce', realizujące strukturę + dostawa + (CZEGO) + (DOKĄD) oraz 1.b 'towar, który jest dostarczany w określone miejsce'.

Możliwa jest więc interpretacja czynnościowa, odpowiadająca prymarnemu znaczeniu leksemu dostawy, lub obiektowa.

Zgodnie z SJP PWN 2004 wynos występuje tylko w grupie przyimkowej konstrukcji brać / kupić / zamówić coś na wynos 'po to, aby skonsumować poza lokalem' (OBIADY TYLKO NA WYNOS), ale słownik ten nie odnotowuje formy wynos. Podaje natomiast jako pierwsze znaczenie czasownika wynosić 'niosąc coś, wychodzić z tym skądś i w ten sposób usuwać to stamtąd'.

Jako obiekt czynności dostawa stanowi wypełnienie miejsca argumentowego, uogólnione leksykalnie przez inkorporowanie do nazwy akomodowanej struktury propozycjonalnej, analogicznie funkcjonuje wynos jako '(zamówiony) obiekt (jadalny) przeznaczony do konsumpcji poza lokalem'. Wynos dodatkowo zawiera w strukturze semantycznej niewystępującą w strukturze czasownika wynosić konieczność przybycia na miejsce, w którym produkt wytworzono. Pojawia się ona w dostawach tylko wówczas, gdy dotyczy czynności zleconej instancji (firmie) zewnętrznej wobec producenta lub produktu, który ma być przez taką firmę dostarczony zamawiającemu. Można zamówić czy zrealizować dostawę czegoś (interpretacja czynnościowa). Wówczas dostawa obejmuje zabranie produktu z jednego miejsca i przemieszcze- 
nie go w inne, co może inkludować czynność wyniesienia i wniesienia produktu. Teoretycznie możliwe jest wyodrębnienie tej czynności jako wynosu, w praktyce komunikacji znaczenie to realizuje się jednak innymi nazwami czynnościowymi, na przykład wywóz (śmieci, gruzu, ziemi). Przemawia to za obiektową interpretacją l. mn. nazwy wynos. Współwystępowanie dostaw z obiektową innowacją leksykalną wynosy skłania do ich spójnej interpretacji obiektowej. Oczekujące w lokalach na stolikach wyłączonych z użycia rzędy toreb kryją w pojemnikach zamówione dania, które mogą być zarówno wynosami, jak i dostawami.

\subsection{Sformułowania nienormatywne i ambiwalentne}

Materiał przynosi przykłady użycia języka odbiegające od normy poprawnościowej, na przykład proszę nie przynosić kartek o leki czy też niepoprawna, zmiękczona forma wyrazu, brak kongruencji między podmiotem i orzeczeniem, także sformułowania niejasne, na przykład dopuszczające różną interpretację dopuszczalnej w lokalu liczby osób - z personelem czy bez:

(21) DO SKLEPU WCHODZIMY POJEDYŃCZO

(22) Informujemy, że w lokalu może przebywać maksymalnie 2 osoby

Zdarzają się sformułowania, które można interpretować jako sprzeczne z treścią rozporządzeń, a także zapewne z intencją nadawcy. Uprzejmy w formie komunikat Seniorów zapraszamy od poniedziałku do piątku w godzinach od 10:0o do 12:0o implikuje, że w innych dniach i godzinach zapraszani są inni interesanci, ale nie seniorzy. Natomiast komunikaty STOP!!! ZAŁÓŻ MASECZKĘ!!! W GODZINACH 10:00-12:0o OBOWIĄZUJE „GODZINA DLA SENIORA” / OD PONIEDZIAEKU DO PIĄTKU W GODZINACH 10:00-12:0o [+cz] OBOWIAZZUJĄ GODZINY SENIORA pozwalają zinterpretować przesłanie przez aktywowanie wiedzy odbiorcy, co oznaczają w tym kontekście godziny seniora / godzina dla seniora oraz senior, podczas gdy komunikat $W$ godzinach od 10:0o do 12:0o obstugiwani sa wyłacznie seniorzy 6o+ nie budzi żadnych wątpliwości interpretacyjnych.

\subsection{Struktury niepełne i wypowiedzenia niezdaniowe}

W analizowanych tekstach występują liczne wypowiedzenia jednozdaniowe, rzadko wielozdaniowe, $\mathrm{w}$ różnym stopniu realizujące potencjał konotacyjny predykatu, co tłumaczy się zróżnicowaną świadomością potrzeby eksplikacji miejsc argumentowych $\mathrm{w}$ celu przekazania obostrzeń pandemicznych. Zwracają uwagę struktury niepełne i wypowiedzenia niezdaniowe. 
Zebrany materiał przynosi zarówno struktury, w których pozostają miejsca niewypełnione z powodu blokowania wypełnienia miejsca podmiotu przez predykat oceniający (Grzegorczykowa 1998: 62): [wersaliki] trzeba zasłaniać nos i usta [个] najlepiej maseczka ochronna, i konstrukcje blokujące pozycję mianownika wskutek przekształcenia gramatycznego: Zaleca się płacenie karta płatnicza (ibid.: 59), jak i niedookreślenie referencjalne:

(23) Kiedy kaszlesz lub kichasz zakrywaj usta i nos.

(24) Zachowaj bezpieczną odległość.

Niewyspecyfikowanie środka, którym należy zakrywać usta i nos, dopuszcza użycie w tym celu zarówno różnych materiałów i narzędzi, jak i łokcia lub dłoni. Podobnie nie wiadomo, jaka odległość jest bezpieczna i czy chodzi o odległość od czegoś czy od kogoś. Jedynie zanurzenie tych wypowiedzeń w kontekście i wiedza aktywowana w procesie przetwarzania informacji przez ramę sytuacyjną pozwalają odbiorcy zrekonstruować znaczenie przypisane im przez nadawcę.

Kończąc ten z konieczności pobieżny przegląd najistotniejszych praktyk językowych zidentyfikowanych w krótkich tekstach regulujących zachowania społeczne w ogólnie dostępnej przestrzeni publicznej, należy przynajmniej nadmienić o komunikatach $\mathrm{w}$ formie wypowiedzeń niezdaniowych, w tym o konstrukcjach bez formy osobowej czasownika zwanych oznajmieniami (ibid.: 14) (Uwaga, Stop) i konstrukcjach nominalnych: TELEPORADA [poniżej numer telefonu] / ZAMÓWIENIA TELEFONICZNE NA UMÓWIONĄ GODZINĘ ODBIÓR OSOBISTY [poniżej odręcznie numer telefonu].

Irmtraud Behr i Hervé Quintin (1996) mówią o różnych typach zdań bezczasownikowych (verblose Sätze - VLS), ilustrując to materiałem pochodzącym głównie z tekstów literackich, w których te licznie występują. Vilmos Ágel (2019: 167-191) wprowadza termin „niezdania” (Nichtsätze - NiS). Renata Grzegorczykowa (1998: 143) wskazuje na wypowiedzenia niezdaniowe jako charakterystyczne dla polszczyzny mówionej i, uwzględniając wcześniejsze klasyfikacje (między innymi Wiśniewski 1994), wyróżnia ich dwa główne typy: takie, które są zrozumiałe bez kontekstu, i takie, które są zależne od kontekstu. W analizowanym materiale znajdują się przykłady oznajmień należących do pierwszej grupy (por. wyżej) i wypowiedzeń niezdaniowych $\mathrm{z}$ wyzerowanym czasownikiem $\mathrm{w}$ formie osobowej, eliptycznych: W ZWIĄZKU Z PANDEMIĄ COVID-19 [+ cz] WEJŚCIE DO SKLEPU TYLKO W MASECZKACH.

Rozwinięcie tego tematu i porównanie typologii wypowiedzeń niezdaniowych w badaniach polonistycznych oraz w badaniach niemieckich i francuskich wymagają szerokiego, odrębnego omówienia. 


\section{Zakończenie}

Powyżej przedstawiono pokrótce najważniejsze praktyki komunikacyjne i językowe, jakie stosuje $\mathrm{w}$ odpowiedzi na uwarunkowane pandemią potrzeby społeczne zróżnicowana instytucjonalnie, wiekowo, płciowo i społecznie rzesza nadawców komunikatów-wywieszek. Wobec konieczności takiego oddziaływania na zachowania społeczne, aby były one zgodne z decyzjami, których celem jest zapobieganie szerzeniu się zakażeń, nadawcy sięgają do różnych środków językowych i typograficznych. Wgląd w rozmaitość stosowanych struktur, leksyki i środków uwypuklania treści pozwolił uchwycić z jednej strony aktualne idiolektalne cechy komunikacji, w tym bliskiej komunikacji ustnej, a z drugiej dynamikę tych drobnych, głównie dyrektywnych komunikatów. Zamierzona krótkość, zwięzłość i dobitność oraz skuteczność perswazyjna komunikacji uaktywniają kreatywność językową i - ogólniej - semiotyczną nadawców w wyrażaniu intencji w stopniu na tyle pełnym i klarownym, aby odbiorca mógł w określonym kontekście zrozumieć przesłanie. Zakładany przy tym horyzont wiedzy odbiorcy niekoniecznie jest wystarczający dla rekonstrukcji projektowanej interpretacji znaczeń. Tak istotna w kontekście pandemii, a nieuświadamiana zmiana w strukturze semantycznej leksemu maska, jako nazwy kluczowego narzędzia $w$ zapobieganiu transmisji wirusa, nie znajduje odbicia w językowej realizacji struktur propozycjonalnych, w których leksem ten występuje w komunikatach. Niepełne językowe realizacje struktur propozycjonalnych, nienormatywne i ambiwalentne sformułowania oraz nietrwała materialna forma licznie obecnych w przestrzeni publicznej miasta, niejednokrotnie odręcznych komunikatów ujawniają zarówno właściwości dzielone z potoczną komunikacją ustną, jak i presję niestabilności oraz poczucie tymczasowości sytuacji.

\section{Literatura}

ÁGel V., 2019, Grammatische Textanalyse (GTA). Eine deszendente Syntax des Deutschen, [w:] L.M. Eichinger, A. Plewnia (red.), Neues vom heutigen Deutsch. Empirisch - methodisch - theoretisch. Jahrbuch 2018 des Instituts für Deutsche Sprache, Berlin - Boston, s. 265-291, https://doi.org/10.1515/9783110622591-013.

Balnat V., 2013, ,Kurzvokal, ,Kurzwort, ,Kurzsatzı, ,Kurztext:: Kürze in der Sprachbeschreibung des Deutschen, „Zeitschrift für Literaturwissenschaft und Linguistik” 170, s. 82-94, https://doi.org/10.1007/BFo3379698.

BeHR I., Quintin H., 1996, Verblose Sätze im Deutschen. Zur syntaktischen und semantischen Einbindung verbloser Konstruktionen in Textstrukturen, Tübingen.

Cierpich-Kozie乇 A., 2020, Koronarzeczywistość - o nowych złożeniach z członem korona$w$ dobie pandemii, „Język Polski” C, s. 102-117, https://doi.org/10.31286/JP.100.4.7.

Domke Ch., 2014, Die Betextung des öffentlichen Raumes: Eine Studie zur Spezifik von Meso-Kommunikation am Beispiel von Bahnhöfen, Innenstädten und Flughäfen, Heidelberg. 
Ehlich K., 2007, Sprache und sprachliches Handeln, t. 3: Diskurs, Narration, Text, Schrift, Berlin - New York, https://doi.org/10.1515/9783110922721.

GrZegorczy KowA R., 1998, Wykłady z polskiej składni, wyd. 2 popr., Warszawa.

Hausendorf H., 2009, Kleine Texte. Über Randerscheinungen von Textualität, „Germanistik in der Schweiz. Online-Zeitschrift der SAGG" 6, s. 5-19.

JANICH N., 2015, Kurze Texte und Kurztexte - transtextuell vernetzt?, [w:] M. Skog-Södersved, E. Reuter, Ch. Rink (red.), Kurze Texte und Intertextualität. Ausgewählte Beiträge der GeFoText-Konferenz vom 26.9. bis 27.9.2013 in Vaasa, Frankfurt am Main, s. 27-48.

Kulczycki E., 2015, Dwa aspekty komunikacji. Założenia komunikologii historycznej, Poznań.

LANDry R., Bourhis R.Y., 1997, Linguistc Landscape and the Ethnolinguistic Vitality: An Empirical Study, „Journal of Language and Social Psychology” 16, nr 1, s. 23-49, https://doi. org/10.1177/0261927X970161002.

LiEDTKe F., 2020, „Achtung! stark befahrene Straße”: Warnhinweise im öffentlichen Raum, [w:] Z. Berdychowska, F. Liedtke (red.), Prägnante Kürze und mehr. Kurztexte und multimodale Kurzformen im öffentlichen Raum, Berlin, s. 19-33, https://doi.org/10.3726/ b176oo.

LiedtKe F., Berdychowska Z., 2020, Kürze, Raum, Material - zur Einleitung, [w:] Z. Berdychowska, F. Liedtke (red.), Prägnante Kürze und mehr. Kurztexte und multimodale Kurzformen im öffentlichen Raum, Berlin, s. 7-15.

Schmitz U., 2016, Multimodale Texttypologie, [w:] N.-M. Klug, H. Stöckl (red.), Handbuch Sprache im multimodalen Kontext, Berlin - Boston, s. 327-347, https://doi.org/10. 1515/9783110296099-015.

Schmitz U., 2018, Media Linguistic Landscapes. Alle Linguistik sollte Medienlinguistik sein, „Journal für Medienlinguistik” 1, nr 1, s. 1-34, https://doi.org/10.21248/jfml.2018.5.

SJP PWN: Słownik języka polskiego, [on-line:] sjp.pwn.pl.

SJP PWN 2004: Słownik języka polskiego PWN, Warszawa 2004 (CD-ROM).

Wielki słownik języka polskiego PAN. Geneza, koncepcja, zasady opracowania, praca zbiorowa, red. P. Żmigrodzki, M. Bańko, B. Batko-Tokarz, J. Bobrowski, A. Czelakowska, M. Grochowski, R. Przybylska, J. Waniakowa, K. Węgrzynek, Kraków 2018.

WiśnIEWsKi M., 1994, Strukturalna charakterystyka polskich wypowiedzeń niezdaniowych, Toruń.

Wојтак M., 2006, Gatunek w formie kolekcji a kolekcja gatunków, „Poznańskie Spotkania Językoznawcze" t. 15, s. 143-152.

WSJP PAN: P. Żmigrodzki (red.), Wielki słownik języka polskiego PAN, [on-line:] wsjp.pl.

\section{Urban Communication and Its Influence on Standards of Behaviour in the Sars-Cov-2 Pandemic Abstract}

The SARS-Cov-2 virus pandemic made it necessary to implement new standards of behaviour in public spaces. As instruments of communication, brief messages in a generally accessible public space aimed at limiting infections by changing social behaviour. This way, such messages contributed to modifying public space in its physical, social and communicative aspects. The article attempts to capture the communicative and linguistic practices used for this purpose. 